\title{
Pathological Signature and Therapeutic Status of NSCLC Patients with Common or Rare Driver Gene Alterations in North China冈A real world retrospective study
}

Hui Zhang

Beijing Tongren Hospital

Xinjie Yang

Beijing Chest Hospital

Xiaodie Qu

beijing chest hospital

Kun Li

Beijing Chest Hospital

Jinghui Wang

Beijing Chest Hospital

Jialin LV

Beijing chest hospital

Xi Li

Beijing chest hoapital

Xinyong Zhang

Beijing Chest hospital

Zichen Liu

Beijing chest hospitcal

Na Qin

Beijing chest hospital

Qian Zhang

Beijing Chest Hospital

Yuhua Wu

Beijing Chest hospital

Li Ma

Beijing Chest Hospital

Fei Gai

amoy diagnostics

Zhan Huang

Amoy diagnostics 


\section{Nanying Che}

Beijing Chest Hospital

Shucai Zhang ( $\nabla$ sczhang@163.com )

Beijing Chest Hospital

\section{Research}

Keywords: Non-small cell lung cancer; Common mutation; Rare mutation; Therapeutic signature; Survival status.

Posted Date: May 22nd, 2020

DOI: https://doi.org/10.21203/rs.3.rs-30399/v1

License: (c) (1) This work is licensed under a Creative Commons Attribution 4.0 International License.

Read Full License 


\section{Abstract}

Background: Although guidelines recommended to test EGFR/ALK/ROS-1 gene alterations in advanced non-small cell lung cancer (NSCLC) patients before treatment, there is now growing evidence that rare driver genes and mutations also can inform targeted therapy and improve outcomes for this traditionally underrepresented population. This study aimed to describe mutational patterns and linked clinical parameters in a Chinese population-based NSCLC cohort.

Methods: This study included patients with pathologically confirmed NSCLC, who were routinely screened for EGFR, KRAS, BRAF, ALK, ROS1, RET, MET, HER2, and PIK3CA mutations by the NMPA approved multigene detection kit. The demographic and clinicopathological data, treatment information, clinical outcomes after first-line treatment, as well as nine driver gene mutation statuses and PD-L1 expression level of these patients were retrospectively collected.

Results: Finally, 431 patients were enrolled, most patients were male (55.9\%), with adenocarcinoma or adenosquamous carcinoma (80.7\%) and in stage IV (50.6\%). Among all the 431 patients, $61.5 \%$ patients were identified with gene mutation including 101 with rare mutation, 164 with 19 del or with L858R mutation. Adenocarcinoma patients have a higher mutation rate (73.6\%), and the mutations mainly occur in EGFR, KRAS, ALK and HER2. While, the gene mutation characteristics in squamous cell carcinoma patients with were relatively simple, only 2 patients with EGFR 19 del and 2 patients with PIK3CA mutation. More PD-L1 expression could detected in patients with rare mutation. The median PFS1 of patients with common mutation (13 months, $95 \% \mathrm{Cl}$ : 9.9-16) was longer than the patients with rare mutation (5 months, $95 \%$ Cl: 0-10.5).

Conclusions: The clinicopathologic features and clinical treatment status among NSCLC patients with common or rare driver gene mutations were different. The survival of patients with rare mutation was worse than that of patients with common mutation. Therefore, more attention should be paid to the treatment strategy and survival status of patients with rare mutations in clinical practice.

\section{Background}

The morbidity and mortality of lung cancer rank first in malignancy in China. It was reported an estimated 733,300 new cases of lung cancer and 610,200 lung cancer-related deaths in China in 2015. ${ }^{[1]}$ Non-small

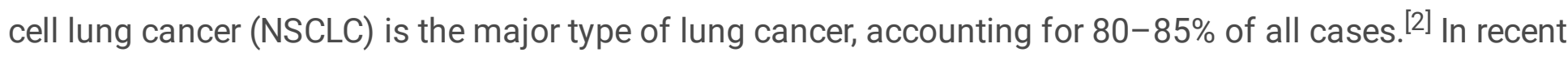
years, the emergence of oncogenic driver gene identification has created a new situation for the treatment of advanced NSCLC. Epidermal growth factor receptor (EGFR) gene mutations can be detected approximately $40 \%-50 \%$ in nonsmoking Asian population. ${ }^{[3]}$ Treatment with EGFR tyrosine kinase inhibitors (EGFR-TKIs) has increased the objective response rate of patients with EGFR mutations (19del, L858R) to about $70 \%$, and the median progression free survival (PFS) has been extended to about 10 months. ${ }^{[4]}$ NSCLC is a disease driven by multiple genes, except for EGFR common mutation, there are still about $20-30 \%$ cases caused by other drugable driver gene mutations. Although the frequency of 
those relatively rare mutations is less than $10 \%$, and some even less than $1 \%$, they can make a big difference in clinical practice. ${ }^{[5]}$

Uncommon EGFR mutations mainly include G719X, exon 20 insertions, S768I, and L861Q. Their overall incidence can reach $5 \%-7 \%$ in NSCLC patients. ${ }^{[6]}$ The average PFS of NSCLC patients with uncommon EGFR mutations treated with gefitinib is only 7.7 months, significantly shorter than the patients with EGFR common mutations. ${ }^{[7]}$ Patients with exon 20 insertions generally have low response or complete resistance to most EGFR-TKIs, while have dramatic response to new drug TAK-788 and pozitinib (NCT02716116,NCT03066206). ${ }^{[8]}$ Human Epidermal Growth Factor Receptor 2 (HER2), a homologous gene of EGFR, has a similar exon 20 mutation type with EGFR, and the incidence rate is about $1 \%-3 \%$. ${ }^{[9]}$ There were no effective targeted drugs for the treatment of HER2 mutant NSCLC patients. The primary results of clinical trial NCT03318939 showed that the patients with HER2 mutation are predicted to benefit from pozitinib. ${ }^{[10,11]}$

Gene fusion, especially kinase gene fusion, is another uncommon mutation type in lung cancer. For example, anaplastic lymphoma kinase ( $A L K$ ), ROS proto-oncogene receptor tyrosine kinase 1 (ROS1), and rearranged during transfection proto-oncogene gene $(R E T)$ are known to have fusion mutations, which account for $2-7 \%, 1-2 \%$, and $1-2 \%$ of advanced NSCLC patients, respectively. The EML4-ALK, CD74ROS1 and KIF5C-RET constitute the major subset of those fusion variations. ${ }^{[12-14]} A L K$, ROS1 and RET rearrangement positive patients appears to be more common in young and never or light smokers diagnosed with adenocarcinoma. ${ }^{[15]}$ Patients with $A L K$ and $R O S 1$ rearrangements can benefit from TKIs, such as crizotinib, which are now widely used in clinical practice. ${ }^{[16,17]}$ For patients with $R E T$ fusion, selective RET inhibitors LOXO-292 (selpercatinib ${ }^{[18]}$ ) and BLU-667 (pralsetinib ${ }^{[19,20]}$ ) are also undergoing phase I/II and I clinical trials, respectively, with preliminary results demonstrating partial response and low incidence of serious adverse events. ${ }^{[5]}$ Mesenchymal-to-epithelial transition factor (MET) exon 14 skipping mutation is another kind of fusion in RNA level with incidence rate of $1 \%-2 \%$ in NSCLC patients, and the mutation positive patients responded to crizotinib or capmatinib. ${ }^{[21]}$ Kirsten rat sarcoma viral oncogene homolog (KRAS) is a downstream molecular of the above kinase genes. The frequency of KRAS mutations in the Chinese NSCLC patients is less than $10 \%$, and it is usually considered to be a drug resistance gene mutation. ${ }^{[22]}$ AMG510, a KRAS G12C inhibitor, and other agents are currently being investigated, and patients with mutation in KRAS may benefit from these novel inhibitors. ${ }^{[23]}$

In the present study, we retrospectively analyzed the mutation profiles of nigh major driver genes, EGFR, $A L K, R O S 1, R E T, H E R 2, K R A S, B R A F, P I K 3 C A$, and MET in 431 Chinese NSCLC patients, as well as their relationship with patient demographic and clinicopathological information. We also collected the treatment data of some patients, and preliminarily described the treatment status and efficacy of patients with driver gene mutations in the real world.

\section{Methods}




\section{Patients and study design}

A total of 431 patients with pathologically confirmed NSCLC from north China were enrolled during the period of 2017 to 2019 in this study. The demographic and clinicopathological data, treatment information, as well as driver gene mutation status and PD-L1 expression level of these patients were retrospectively collected. The whole patients were divided into two groups, patients with common mutation (EGFR 19del or L858R) and patients with rare mutation (all the other eight driver genes and uncommon EGFR mutations). For the survival data analysis, we calculated the progression-free survival of these two groups of patients receiving the first-line treatment (PFS1).

\section{Driver Gene Mutation Detection}

All the tumor tissue and cytology samples were fixed in $10 \%$ neutral formalin buffer and embedded in paraffin. Five-ten sections ( $5 \mu \mathrm{M}$ thickness) of tumor samples were used for both DNA and RNA extraction by using AmoyDx FFPE DNA/RNA Kit (Amoy Diagnostics, Xiamen, China) according to the manufacturer's instructions. The quantity and quality of isolated DNA and RNA were determined with trace ultraviolet spectrophotometer.

The isolated DNA and RNA were tested for multiple genomic alterations by AmoyDx Multi-Gene assay (Amoy Diagnostics, Xiamen, China). Experimental procedure and data analysis were followed the manufacturer's instructions. This qPCR assays for detection of oncogenic driver alterations have been approved by China NMPA.

\section{Pd-I1 Expression Detection}

PD-L1 expressions were detected by PD-L1 IHC 22C3 assay kit according to the manufacturer's instructions. The Dako Autostainer Link 48 (ASL48) immunohistochemical staining machine was used. The data analysis was followed the manufacturer's instructions as well.

\section{Statistical analysis}

The data were analyzed using SPSS software version 19 (IBM Corp., Armonk, NY, USA). Chi-square test was used to evaluate differences in the clinicopathological characteristics between the common mutation and rare mutation groups. Logistic regression analysis was used to evaluate independent factors associated with driver gene mutation. Kaplan-Meier analysis was performed for PFS1 curves, and statistical significance was assessed using the log-rank test. $p<0.05$ was considered to be statistically significant. Graphic drawing was performed using GraphPad Prism 6.0 software (GraphPad Software, Inc., La Jolla, CA, USA).

\section{Results}




\section{Demographic and clinicopathological features of patients}

The basic demographic and clinicopathological data of the 431 NSCLC patients, including age, gender, smoking history, family history, and chronic disease history, clinical stage, and pathological type are shown in Table 1. Most of the patients enrolled in this study were younger than 65 years old, male, no family history and chronic disease history. There was approximately equal number of former smoker and patients without smoking history. Patients in this study were distributed in stage I-IV, according to the American Journal of Critical Care Cancer Staging Manual (version eight), with the most patients in stage IV (50.6\%). The proportion of stage I, II, and III were $22.5 \%, 5.8 \%$, and $20.0 \%$ respectively. Regarding pathological subtype, adenocarcinoma or adenosquamous carcinoma was the most common subtype $(80.7 \%)$, and then was the squamous carcinoma (14.4\%). $60.3 \%$ of the specimens used for molecular diagnosis were biopsy specimens, surgical and cytology specimens were $31.6 \%$ and $7.9 \%$ separately. A total of 315 specimens had the PD-L1 test records, the positive rate was $49.5 \%$. 
Table 1

Demographic and clinicopathological data of 431 NSCLC patients

\begin{tabular}{|c|c|c|c|}
\hline & \multicolumn{2}{|c|}{ Overall $(n=431)$} & \multirow{2}{*}{$\begin{array}{l}P \text { value }(95 \% \mathrm{Cl}) \\
0.046(0.041-0.50)\end{array}$} \\
\hline Age & & & \\
\hline$<65$ & 237 & $55.0 \%$ & \\
\hline$>=65$ & 194 & $45.0 \%$ & \\
\hline Gender & & & $0.018(0.015-0.021)$ \\
\hline Male & 241 & $55.9 \%$ & \\
\hline Female & 190 & $44.1 \%$ & \\
\hline Smoking status & & & $0.810(0.803-0.818)$ \\
\hline Never & 218 & $50.6 \%$ & \\
\hline Former & 213 & $49.7 \%$ & \\
\hline Family history of cancer & & & $<0.01$ \\
\hline Yes & 71 & $16.5 \%$ & \\
\hline No & 360 & $83.5 \%$ & \\
\hline History of chronic diseases & & & $<0.01$ \\
\hline Yes & 50 & $11.6 \%$ & \\
\hline No & 381 & $88.4 \%$ & \\
\hline Clinical stage & & & $<0.01$ \\
\hline 1 & 97 & $22.5 \%$ & \\
\hline II & 25 & $5.8 \%$ & \\
\hline III & 86 & $20.0 \%$ & \\
\hline IV & 218 & $50.6 \%$ & \\
\hline Not available & 5 & $1.2 \%$ & \\
\hline Specimen type & & & $<0.01$ \\
\hline Biopsy specimen & 260 & $60.3 \%$ & \\
\hline Cytology specimen & 34 & $7.9 \%$ & \\
\hline Surgical specimen & 136 & $31.6 \%$ & \\
\hline Pathological type & & & $<0.01$ \\
\hline
\end{tabular}




\begin{tabular}{|llll|}
\hline & Overall $(\mathrm{n}=\mathbf{4 3 1})$ & P value (95\% Cl) \\
\hline Adenocarcinoma or adenosquamous carcinoma & 348 & $80.7 \%$ & \\
\hline Squamous Carcinoma & 62 & $14.4 \%$ & \\
others & 21 & $4.9 \%$ & \\
PD-L1 $(\mathrm{n}=315)$ & & & 0.018 \\
Positive & 156 & $49.5 \%$ & \\
Negative & 159 & $50.5 \%$ & \\
\hline
\end{tabular}

\section{Oncogenic Driver Gene Alterations In Nsclc Patients}

The multigene PCR detection data of 431 patients were obtained, shown in Fig. 1. Among all the 431 patients, $61.5 \%$ patients were identified with gene mutation. The most frequent genomic alterations (38.1\%) in this Chinese NSCLC cohort was the common EGFR mutations, and other frequent genomic alterations were as follows: KRAS mutation (8.1\%), uncommon EGFR mutations (5.3\%), ALK rearrangement (3.9\%), HER2 mutations (1.9\%), BRAF mutation (1.4\%), RET rearrangement (1.2\%), PIK3CA mutation (0.7\%), ROS1 rearrangement (0.5\%), and MET exon 14 skipping (0.5\%).

There was a similar gene mutation pattern in adenocarcinoma and adenosquamous carcinoma patients. The difference in oncogenic driver mutations between adenocarcinoma and squamous cell carcinoma patients was mainly manifested in the high gene mutation rate (73.6\%) in adenocarcinoma patients, and the mutations were mainly occurred in EGFR, KRAS, ALK and HER2. However, the genetic mutation characteristics of patients with squamous cell carcinoma were relatively simple, of the 62 squamous cell carcinoma patients in this study, EGFR 19 del was only detected in 2 patients and 2 patients was detected with PIK3CA mutation.

\section{Comparison of the characteristics between common and rare mutations in NSCLC patients}

Among the 164 patients with common mutations and the 101 patients with rare mutations, there was no statistics difference in age, smoking history, family history of cancer, chronic disease history and clinical stage ( $p>0.05)$. In terms of gender, female accounted for the majority $(61.0 \%)$ in common mutation group, showing a statistical difference, while there was no significant difference in the proportion of male $(55.4 \%)$ and female (44.6\%) in rare mutation group. In this study, more than $90 \%$ samples were obtained from biopsy $(60.3 \%)$ and surgery $(31.6 \%)$. Although the distribution of sample types in each group is not very uniform, the proportion of each sample type is not statistically different between the two groups and the pathological types also has a similar phenomenon between the two groups. Among all the patients, 
PD-L1 expression data were obtained in 315 patients, and the positive rate was 49.5\%. PD-L1-positive cases accounted for $29.9 \%(49 / 164)$ in common mutation group and $40.6 \%(41 / 101)$ in rare mutation group, the difference was statistically significant (Table 2 ). 
Table 2

Comparison of characteristics between common mutation and rare mutations in NSCLC patients

\begin{tabular}{|c|c|c|c|}
\hline Characteristics & $\begin{array}{l}\text { Patients with common } \\
\text { mutation } \\
(n=164)\end{array}$ & $\begin{array}{l}\text { Patients with rare } \\
\text { mutation } \\
(n=101)\end{array}$ & $\begin{array}{l}P \text { value } \\
(95 \% \mathrm{Cl})\end{array}$ \\
\hline & $N(\%)$ & $N(\%)$ & \\
\hline Age & & & 0.614 \\
\hline$<65$ & $93(56.7 \%)$ & $61(60.4 \%)$ & $(0.604,0.624)$ \\
\hline$>=65$ & $71(43.3 \%)$ & 40(39.6\%) & \\
\hline Gender & & & 0.012 \\
\hline Male & $64(39.0 \%)$ & $56(55.4 \%)$ & $(0.10,0.014)$ \\
\hline Female & $100(61.0 \%)$ & $45(44.6 \%)$ & \\
\hline Smoking status & & & 0.070 \\
\hline Never & 110(67.1\%) & $56(55.4 \%)$ & $(0.065,0.075)$ \\
\hline Former & $54(32.9 \%)$ & $45(44.6 \%)$ & \\
\hline Family history of cancer & & & 0.746 \\
\hline Yes & $31(18.9 \%)$ & 17(16.8\%) & $(0.737,0.754)$ \\
\hline No & 133(81.1\%) & 84(83.2\%) & \\
\hline Chronic diseases history & & & $0.311(0.302$ \\
\hline Yes & $20(12.2 \%)$ & $8(7.9 \%)$ & \\
\hline No & 144(87.8\%) & $93(92.1 \%)$ & \\
\hline Clinical stage & & & 0.757 \\
\hline I & $50(30.5 \%)$ & $21(20.8 \%)$ & $(0.748,0.765)$ \\
\hline II & $2(1.2 \%)$ & $8(7.9 \%)$ & \\
\hline III & 17(10.4\%) & $22(21.8 \%)$ & \\
\hline IV & $94(57.3 \%)$ & $50(49.5 \%)$ & \\
\hline Specimen type & & & 0.665 \\
\hline Biopsy specimen & $94(57.3 \%)$ & $60(59.4 \%)$ & $(0.656,0.774)$ \\
\hline Cytology specimen & $14(8.5 \%)$ & $10(9.9 \%)$ & \\
\hline Surgical specimen & $56(34.1 \%)$ & $31(30.7 \%)$ & \\
\hline
\end{tabular}




\begin{tabular}{|c|c|c|c|}
\hline Characteristics & $\begin{array}{l}\text { Patients with common } \\
\text { mutation } \\
(n=164)\end{array}$ & $\begin{array}{l}\text { Patients with rare } \\
\text { mutation } \\
(n=101)\end{array}$ & $\begin{array}{l}P \text { value } \\
(95 \% \mathrm{Cl})\end{array}$ \\
\hline Pathological type & & & 0.264 \\
\hline $\begin{array}{l}\text { Adenocarcinoma or } \\
\text { adenosquamous carcinoma }\end{array}$ & $160(97.6 \%)$ & $96(95.0 \%)$ & $(0.255,0.272)$ \\
\hline Squamous Carcinoma & $2(1.2 \%)$ & $2(2.0 \%)$ & \\
\hline others & $2(1.2 \%)$ & $3(3.0 \%)$ & \\
\hline PD-L1 & & & 0.001 \\
\hline Positive & $49(29.9 \%)$ & $41(40.6 \%)$ & $(0.001,0.002)$ \\
\hline negative & $79(48.2 \%)$ & $27(26.7 \%)$ & \\
\hline
\end{tabular}

In addition, logistic regression was used to analyze the risk factors associated with mutation status. The independent risk factors for common mutations were smoking history; pathology subtype and PD-L1 expression level, for rare mutations were pathology subtype and PD-L1 expression level (data not shown).

\section{Treatment Data Of Nsclc Patients After Genetic Analysis}

A total of 241 treatment records of NSCLC patients were obtained after genetic testing, details are shown in Table 3. For patients with common mutation, mono or combined targeted therapy was preferred, including $91 \%$ of the patients. For patients with rare mutations, $45.8 \%$ received mono or combined targeted therapy, the same number of patients received traditional treatment, and another $8.5 \%$ received mono or combined immunotherapy owing to enter clinical trials. Forty-six advanced patients achieved first-line treatment progress. The proportions of these patients carrying common mutation, rare mutation and with no detected mutations were $47.8 \%(22), 17.4 \%(8)$, and $34.8 \%(16)$, respectively. Their treatment options are shown in Table 3. The median PFS1 of patients with common mutation was longer than the other two groups, which was 13 months (95\% Cl: 9.9-16). The patients with rare mutation and no detected mutations were 5 months ( $95 \% \mathrm{Cl}$ : 0-10.5), and 5 months ( $95 \% \mathrm{Cl}: 1.1-8.9)$ respectively. However, due to the small amount of data, there was no statistical difference $(p=0.270)$ (Fig. 2). It is worth noting that four of the patients who were no detected mutations for the first genetic test, however, after the progress of chemotherapy the second driver gene mutation detection shown 2 of them with common mutation, and 2 of them with HER2 exon 20 insertions (Table 4). 
Table 3

Details of gene mutation status and subsequent treatment options

\begin{tabular}{|c|c|c|c|c|}
\hline & All patients & $\begin{array}{l}\text { Patients with } \\
\text { common mutation }\end{array}$ & $\begin{array}{l}\text { Patients with } \\
\text { rare mutation }\end{array}$ & $\begin{array}{l}\text { Patients with } \\
\text { wild type }\end{array}$ \\
\hline & \multicolumn{4}{|c|}{241 patients with treatment recorded } \\
\hline & $N=241$ & $N=100$ & $N=59$ & $N=82$ \\
\hline $\begin{array}{l}\text { mono or combined } \\
\text { targeted therapy }\end{array}$ & $124(51.4 \%)$ & $91(91 \%)$ & $27(45.8 \%)$ & $6(7.3 \%)$ \\
\hline $\begin{array}{l}\text { mono or combined } \\
\text { Immunotherapy }\end{array}$ & $16(6.6 \%)$ & 0 & $5(8.5 \%)$ & $11(13.4 \%)$ \\
\hline \multirow[t]{3}{*}{ Other } & $101(41.9 \%)$ & $9(9 \%)$ & $27(45.8 \%)$ & $65(79.3 \%)$ \\
\hline & \multicolumn{4}{|c|}{46 patients with first line treatment progressed } \\
\hline & $N=46$ & $N=22$ & $N=8$ & $N=16$ \\
\hline $\begin{array}{l}\text { mono or combined } \\
\text { targeted therapy }\end{array}$ & $26(56.5 \%)$ & $21(95.5 \%)$ & $3(37.5 \%)$ & $2(12.5 \%)$ \\
\hline $\begin{array}{l}\text { mono or combined } \\
\text { Immunotherapy }\end{array}$ & $1(2.2 \%)$ & 0 & $1 *(12.5 \%)$ & 0 \\
\hline Other & $19(21.3 \%)$ & $1(4.5 \%)$ & $4(50 \%)$ & $14(87.5 \%)$ \\
\hline
\end{tabular}

Table 4

The basic clinical and genetic information of the 4 patients with the first genetic test negative

\begin{tabular}{|lllllll|}
\hline $\begin{array}{l}\text { Sample } \\
\text { NO. }\end{array}$ & Gender & $\begin{array}{l}\text { Smoking } \\
\text { status }\end{array}$ & $\begin{array}{l}\text { Pathological } \\
\text { subtype }\end{array}$ & $\begin{array}{l}\text { 1st gene } \\
\text { mutation } \\
\text { testing }\end{array}$ & $\begin{array}{l}\text { 1st line } \\
\text { therapy }\end{array}$ & $\begin{array}{l}\text { 2nd gene } \\
\text { mutation } \\
\text { testing after } \\
\text { progression }\end{array}$ \\
\hline 174 & female & Never & NSCLC & negative & chemotherapy & EGFR L858R \\
\hline 209 & male & Yes & Adenocarcinoma & negative & chemotherapy & EGFR 19del \\
\hline 361 & female & Never & Adenocarcinoma & negative & chemotherapy & HER2 20ins \\
\hline 444 & female & Never & Adenocarcinoma & negative & chemotherapy & HER2 20ins \\
\hline
\end{tabular}

\section{Discussion}

Non-small cell lung cancer is a genetic disease with high heterogeneity. The development process of cancer is related to driver genes, and the mutation status of driver genes also determines the choice of clinical treatment. It is reported that in Chinese NSCLC patients, the major driver genes include EGFR, ALK, ROS1, RET, HER2, MET, KARS, BRAF and PIK3CA. ${ }^{[5]}$ In the present study, we retrospectively analyzed the major driver gene mutation status in 431 NSCLC patients by the NMPA approved multi-gene detection kit. The nine-major driver gene mutation rate was $61.5 \%$ in all patients, which was higher in lung 
adenocarcinoma or adenosquamous carcinoma patients (73.6\%), and the highest mutation rate in adenocarcinoma and adenosquamous carcinoma patients was the common EGFR mutation, $38.1 \%$ and $46.0 \%$, respectively. For the rare mutations, $K R A S(8.1 \%$ in adenocarcinoma, and $9.2 \%$ in adenosquamous carcinoma), uncommon EGFR mutation (5.3\% in adenocarcinoma, and $6.6 \%$ in adenosquamous carcinoma in adenosquamous carcinoma), $\operatorname{ALK}(3.9 \%$ in adenocarcinoma, and $4.9 \%$ in adenosquamous carcinoma), HER2 (1.9\% in adenocarcinoma, and $2.3 \%$ in adenosquamous carcinoma), and BRAF $(1.4 \%$ in adenocarcinoma, and $1.7 \%$ in adenosquamous carcinoma) were the top five mutation types. Unfortunately, in our study the detection method was based on PCR, and most rare mutations cannot be distinguished the mutation sites, so the details of mutations cannot be shown here. The nine-major driver gene mutation frequency in squamous cell carcinoma patients in our study was $6.4 \%$, including $3.2 \%$ of EGFR $19 \mathrm{del}$ and $3.2 \%$ of PIK3CA mutation, which was consistent with the previous studies. ${ }^{[6]}$ This also indicates that for patients with squamous cell carcinoma, it is necessary to improve the method to increase the positive detection rate of the major driver genes in clinical testing.

To analyze the relationship between the demographic and clinicopathological data with gene mutations can reveal the clinical characteristics of patients with mutations and provide references for clinical diagnosis and treatment. As it was reported that histology and smoking status are associated with EGFR status ${ }^{[24]}$, which was proved in our study. For gender, previous studies indicated that the detection rate of EGFR mutations in women was higher, partly due to the higher proportion of non-smokers in the female population. ${ }^{[24,25]}$ In the present study, female patients had a higher incidence of common mutations than those with rare mutations. Rare mutations occurred more frequently in male patients. Apart from gender, the expression of PD-L1 was also observed oppositely in common mutation and rare mutations groups with significantly difference. PD-L1 expression was positively correlated with rare mutation and negatively with common mutation in this study. Previous reports only consistently shown that KRAS mutations are positively correlated with PD-L1 expression, while the relationship between other gene mutation status and PD-L1 expression shown inconsistent conclusions. ${ }^{[26]}$ Therefore, in clinical practice, it is meaningful to pay more attention to rare mutations in male patients with adenocarcinoma. Also, for patients with rare mutations, further detection of PD-L1 expression level will have more hints for clinical treatment.

In China, the Chinese Society of Clinical Oncology (CSCO) guidelines, have taken the lead in compiling annual diagnosis and therapeutic approaches for cancer patients. In the CSCO guidelines, EGFR mutations, $A L K$ and $R O S 1$ rearrangements and their targeted drugs are recommended for routine clinical practice due to the limited availability of drugs. It is recommended to detect the expression of PD-L1 in patients with negative mutations of EGFR, $A L K$ and ROS1 and to adopt the corresponding immunotherapy regimen... ${ }^{[5,27]}$ In our study, treatment information was collected from $55.9 \%(241 / 431)$ of patients after genetic testing. For patients with common mutation, $91 \%$ received mono or combined targeted therapy compared with $45.8 \%$ of patients with rare mutation. The rare mutation types in these patients with treatment information were 11 uncommon EGFR mutation, 11 ALK fusion, 2 BRAFV600E mutation,2 MET exon 14 skipping, and 1 HER2 20ins. Among all the 241 patients with treatment 
information, only $6.6 \%$ of patients received mono or combined immunotherapy, and most patients chose this treatment because they participated in clinical trials. Due to the disparities and imbalance in resources, immunotherapy is still in its infancy in clinical practice in China.

In this study, we calculated the survival data from 46 patients who underwent first-line therapy after genetic testing based on limited data. Regardless of the specific treatment regimen adopted by these patients, only the relationship between the genetic mutation of patients and the median PFS1 was analyzed, we found some clues. Although the data were not statistically different, it could be found that the median PFS1 of patients with rare mutations was similar to mutation-negative patients, while shorter than the patients with common mutations. Previous studies have reported that the average PFS of NSCLC patients with uncommon EGFR mutations treated with EGFR-TKIs was significantly shorter than the patients with common EGFR mutations. ${ }^{[7,8]}$ This also suggests that for patients with rare mutations, better efficacy targeted drugs are needed in clinical practice. Furthermore, we identified 4 patients with negative primary genetic testing, however the driver gene mutation detection was positive after of chemotherapy progressed. In a study about the influence of chemotherapy on the status of EGFR mutation, the result showed that $24(9.1 \%)$ of 264 NSCLC patients with EGFR wild type, but became mutant after first-line chemotherapy. ${ }^{[28]}$ Furthermore, compared with first-line treatment, the efficiency of second-line EGFR-TKI treatment was lower. ${ }^{[29,30]}$ Therefore, for NSCLC patients, if possible, the mutation status should be fully detected at the initial test. In addition, if the initial test is negative, the driver gene mutation status needs to be detected again before the second-line treatment.

There are also several limitations in this study. Firstly, the sample size is not large enough, especially the patients with rare mutations, so further investigation in larger sample size is warranted to validate the results of this work. Secondly, the collection of treatment records is incomplete, leading to inablilty to perform deeper analysis of survival data. Finally, due to the limited availability of new targeted drugs, the majority of patients with rare mutations did not have the opportunity to receive targeted therapy. Therefore, the resulting PFS may not objectively reflect the characteristics of the disease itself.

\section{Conclusions}

NSCLC patients with rare and common driver gene mutations differ in clinicopathological characteristics and clinical treatment status. Although the frequency of rare driver gene mutations is low, the number of patients in this group is also quite large due to the huge base of lung cancer patients. In clinical practice, these patients should be accurately diagnosed and more personalized attention should be paid in the follow-up treatment.

\section{Declarations}

\section{Ethics approval and consent to participate}

Ethics Committee of Beijing Chest Hospital, Capital Medical University, Beijing, China. N.0.2019(62) 
The consent to participate was waived

Consent for publication

Not applicable

Availability of data and materials

The datasets used and/or analyzed during the current study are available from the corresponding author on reasonable request.

Competing interests:

The authors declare that they have no competing interests.

Funding

Not applicable

Authors' contributions

Study design, ethical application and integrated management: Shucai Zhang and Nanying Che

Patient screening and patient clinical data collection: Hui Zhang, Xinjie Yang, Jinghui Wang, Jialin Lv, Xi Li, Xinyong Zhang, Zichen Liu, Na Qin, Zhang Quan, Yuhua Wu, Li Ma

Patient pathological data and molecular diagnostic data collection: Nanying Che, Xiaodie Qu, Kun Li

Data analysis, writing and review the manuscript: Fei Gai, Zhan Huang, Shucai Zhang, Hui Zhang, Nanying Che

The authors read and approved the final manuscript.

\section{References}

[1] Chen W, Zheng R, Baade PD, Zhang S, Zeng H, Bray F, Jemal A, Yu XQ, He J: Cancer statistics in China, 2015. CA Cancer J Clin 2016; 66: 115-132.

[2] Molina JR, Yang P, Cassivi SD, Schild SE, Adjei AA: Non-small cell lung cancer: epidemiology, risk factors, treatment, and survivorship. Mayo Clin Proc 2008; 83: 584-594.

[3] Suh JH, Johnson A, Albacker L, Wang K, Chmielecki J, Frampton G, Gay L, Elvin JA, Vergilio JA, Ali S, Miller VA, Stephens PJ, Ross JS: Comprehensive Genomic Profiling Facilitates Implementation of the National Comprehensive Cancer Network Guidelines for Lung Cancer Biomarker Testing and Identifies Patients Who May Benefit From Enrollment in Mechanism-Driven Clinical Trials. Oncologist 2016; 21: 684-691. 
[4] Kumarakulasinghe NB, van Zanwijk N, Soo RA: Molecular targeted therapy in the treatment of advanced stage non-small cell lung cancer (NSCLC). Respirology 2015; 20: 370-378.

[5] Wu X-CZaY-L: Precision cancer medicine and immunology in China. science 2018; 359.

[6] Wen S, Dai L, Wang L, Wang W, Wu D, Wang K, He Z, Wang A, Chen H, Zhang P, Dong X, Dong YA, Wang K, Yao M, Wang M: Genomic Signature of Driver Genes Identified by Target Next-Generation Sequencing in Chinese Non-Small Cell Lung Cancer. Oncologist 2019; 24: e1070-e1081.

[7] Chiu CH, Yang CT, Shih JY, Huang MS, Su WC, Lai RS, Wang CC, Hsiao SH, Lin YC, Ho CL, Hsia TC, Wu MF, Lai CL, Lee KY, Lin CB, Yu-Wung Yeh D, Chuang CY, Chang FK, Tsai CM, Perng RP, Chih-Hsin Yang J: Epidermal Growth Factor Receptor Tyrosine Kinase Inhibitor Treatment Response in Advanced Lung Adenocarcinomas with G719X/L861Q/S768I Mutations. J Thorac Oncol 2015; 10: 793-799.

[8] Yang JCH, Sequist LV, Geater SL, Tsai C-M, Mok TSK, Schuler M, Yamamoto N, Yu C-J, Ou S-HI, Zhou C, Massey D, Zazulina V, Wu Y-L: Clinical activity of afatinib in patients with advanced non-smallcell lung cancer harbouring uncommon EGFR mutations: a combined post-hoc analysis of LUX-Lung 2, LUX-Lung 3, and LUX-Lung 6. The Lancet Oncology 2015; 16: 830-838.

[9] Song Z, Yu X, Shi Z, Zhao J, Zhang Y: HER2 mutations in Chinese patients with non-small cell lung cancer. Oncotarget 2016; 7: 78152-78158.

[10] Heymach J, Negrao M, Robichaux J, Carter B, Patel A, Altan M, Gibbons D, Fossella F, Simon G, Lam V, Blumenschein G, Tsao A, Kurie J, Mott F, Jenkins D, Mack D, Feng L, Roeck B, Yang Z, Papadimitrakopoulou V, Elamin Y: OA02.06 A Phase II Trial of Poziotinib in EGFR and HER2 exon 20 Mutant Non-Small Cell Lung Cancer (NSCLC). Journal of Thoracic Oncology 2018; 13: S323-S324.

[11] Jebbink M, de Langen AJ, Boelens MC, Monkhorst K, Smit EF: The force of HER2 - A druggable target in NSCLC? Cancer Treat Rev 2020; 86: 101996.

[12] Li Y, Pan Y, Wang R, Sun Y, Hu H, Shen X, Lu Y, Shen L, Zhu X, Chen H: ALK-rearranged lung cancer in Chinese: a comprehensive assessment of clinicopathology, IHC, FISH and RT-PCR. PLoS One 2013; 8: e69016.

[13] Arcila ME, Nafa K, Chaft JE, Rekhtman N, Lau C, Reva BA, Zakowski MF, Kris MG, Ladanyi M: EGFR Exon 20 Insertion Mutations in Lung Adenocarcinomas: Prevalence, Molecular Heterogeneity, and Clinicopathologic Characteristics. Molecular Cancer Therapeutics 2013; 12: 220-229.

[14] Zhang L, Jiang T, Zhao C, Li W, Li X, Zhao S, Liu X, Jia Y, Yang H, Ren S, Zhou C: Efficacy of crizotinib and pemetrexed-based chemotherapy in Chinese NSCLC patients with ROS1 rearrangement. Oncotarget 2016; 7: 75145-75154.

[15] Shaw AT, Yeap BY, Mino-Kenudson M, Digumarthy SR, Costa DB, Heist RS, Solomon B, Stubbs H, Admane S, McDermott U, Settleman J, Kobayashi S, Mark EJ, Rodig SJ, Chirieac LR, Kwak EL, Lynch TJ, 
lafrate AJ: Clinical features and outcome of patients with non-small-cell lung cancer who harbor EML4ALK. J Clin Oncol 2009; 27: 4247-4253.

[16] Solomon BJ, Mok T, Kim DW, Wu YL, Nakagawa K, Mekhail T, Felip E, Cappuzzo F, Paolini J, Usari T, lyer S, Reisman A, Wilner KD, Tursi J, Blackhall F, Investigators P: First-line crizotinib versus chemotherapy in ALK-positive lung cancer. N Engl J Med 2014; 371: 2167-2177.

[17] Camidge DR, Kim HR, Ahn MJ, Yang JC, Han JY, Lee JS, Hochmair MJ, Li JY, Chang GC, Lee KH, Gridelli C, Delmonte A, Garcia Campelo R, Kim DW, Bearz A, Griesinger F, Morabito A, Felip E, Califano R, Ghosh S, Spira A, Gettinger SN, Tiseo M, Gupta N, Haney J, Kerstein D, Popat S: Brigatinib versus Crizotinib in ALK-Positive Non-Small-Cell Lung Cancer. N Engl J Med 2018; 379: 2027-2039.

[18] Drilon A, Oxnard GR, Wirth L, Besse B, Gautchi O, Tan DS ea: Registrational results of LIBRETTO001: A phase 1/2 trial of LOXO-292 in patients with RET fusion-positive lung cancers. IASLC 20192019.

[19] Gainor JF, Lee DH, Curigliano G, Doebele RC, Kim D-W, Baik CS ea: Clinical activity and tolerability of BLU-667, a highly potent and selective RET inhibitor, in patients (pts) with advanced RETfusion+ non-small cell lung cancer (NSCLC). J Clin Oncol. 2019; 37.

[20] Subbiah V, Gainor JF, Rahal R, Brubaker JD, Kim JL, Maynard M, Hu W, Cao Q, Sheets MP, Wilson D, Wilson KJ, DiPietro L, Fleming P, Palmer M, Hu MI, Wirth L, Brose MS, Ou SI, Taylor M, Garralda E, Miller S, Wolf B, Lengauer C, Guzi T, Evans EK: Precision Targeted Therapy with BLU-667 for RET-Driven Cancers. Cancer Discov 2018; 8: 836-849.

[21] Hughes VS, Siemann DW: Have Clinical Trials Properly Assessed c-Met Inhibitors? Trends Cancer 2018; 4: 94-97.

[22] Li S, Li L, Zhu Y, Huang C, Qin Y, Liu H, Ren-Heidenreich L, Shi B, Ren H, Chu X, Kang J, Wang W, Xu J, Tang K, Yang H, Zheng Y, He J, Yu G, Liang N: Coexistence of EGFR with KRAS, or BRAF, or PIK3CA somatic mutations in lung cancer: a comprehensive mutation profiling from 5125 Chinese cohorts. $\mathrm{Br} \mathrm{J}$ Cancer 2014; 110: 2812-2820.

[23] Canon J, Rex K, Saiki AY, Mohr C, Cooke K, Bagal D, Gaida K, Holt T, Knutson CG, Koppada N, Lanman BA, Werner J, Rapaport AS, San Miguel T, Ortiz R, Osgood T, Sun JR, Zhu X, McCarter JD, Volak LP, Houk BE, Fakih MG, O'Neil BH, Price TJ, Falchook GS, Desai J, Kuo J, Govindan R, Hong DS, Ouyang W, Henary H, Arvedson T, Cee VJ, Lipford JR: The clinical KRAS(G12C) inhibitor AMG 510 drives anti-tumour immunity. Nature 2019; 575: 217-223.

[24] Wei WE, Mao NQ, Ning SF, Li JL, Liu HZ, Xie T, Zhong JH, Feng Y, Wei CH, Zhang LT: An Analysis of EGFR Mutations among 1506 Cases of Non-Small Cell Lung Cancer Patients in Guangxi, China. PLoS One 2016; 11: e0168795. 
[25] Kosaka T, Yatabe Y, Endoh H, Kuwano H, Takahashi T, Mitsudomi T: Mutations of the epidermal growth factor receptor gene in lung cancer: biological and clinical implications. Cancer Res 2004; 64: 8919-8923.

[26] Karatrasoglou EA, Chatziandreou I, Sakellariou S, Stamopoulos K, Kavantzas N, Lazaris AC, Korkolopoulou P, Saetta AA: Association between PD-L1 expression and driver gene mutations in nonsmall cell lung cancer patients: correlation with clinical data. Virchows Arch 2020.

[27] Guidelines of Chinese Society of Clinical Oncology(CSCO) Primary Lung Cancer. 2020.

[28] Bai H, Wang Z, Chen K, Zhao J, Lee JJ, Wang S, Zhou Q, Zhuo M, Mao L, An T, Duan J, Yang L, Wu M, Liang Z, Wang Y, Kang X, Wang J: Influence of chemotherapy on EGFR mutation status among patients with non-small-cell lung cancer. J Clin Oncol 2012; 30: 3077-3083.

[29] Mok TS, Wu YL, Thongprasert S, Yang CH, Chu DT, Saijo N, Sunpaweravong P, Han B, Margono B, Ichinose Y, Nishiwaki Y, Ohe Y, Yang JJ, Chewaskulyong B, Jiang H, Duffield EL, Watkins CL, Armour AA, Fukuoka M: Gefitinib or carboplatin-paclitaxel in pulmonary adenocarcinoma. N Engl J Med 2009; 361: 947-957.

[30] Maemondo M, Inoue A, Kobayashi K, Sugawara S, Oizumi S, Isobe H, Gemma A, Harada M, Yoshizawa H, Kinoshita I, Fujita Y, Okinaga S, Hirano H, Yoshimori K, Harada T, Ogura T, Ando M, Miyazawa H, Tanaka T, Saijo Y, Hagiwara K, Morita S, Nukiwa T, North-East Japan Study G: Gefitinib or chemotherapy for non-small-cell lung cancer with mutated EGFR. N Engl J Med 2010; 362: 2380-2388.

\section{Figures}




\section{All patients}

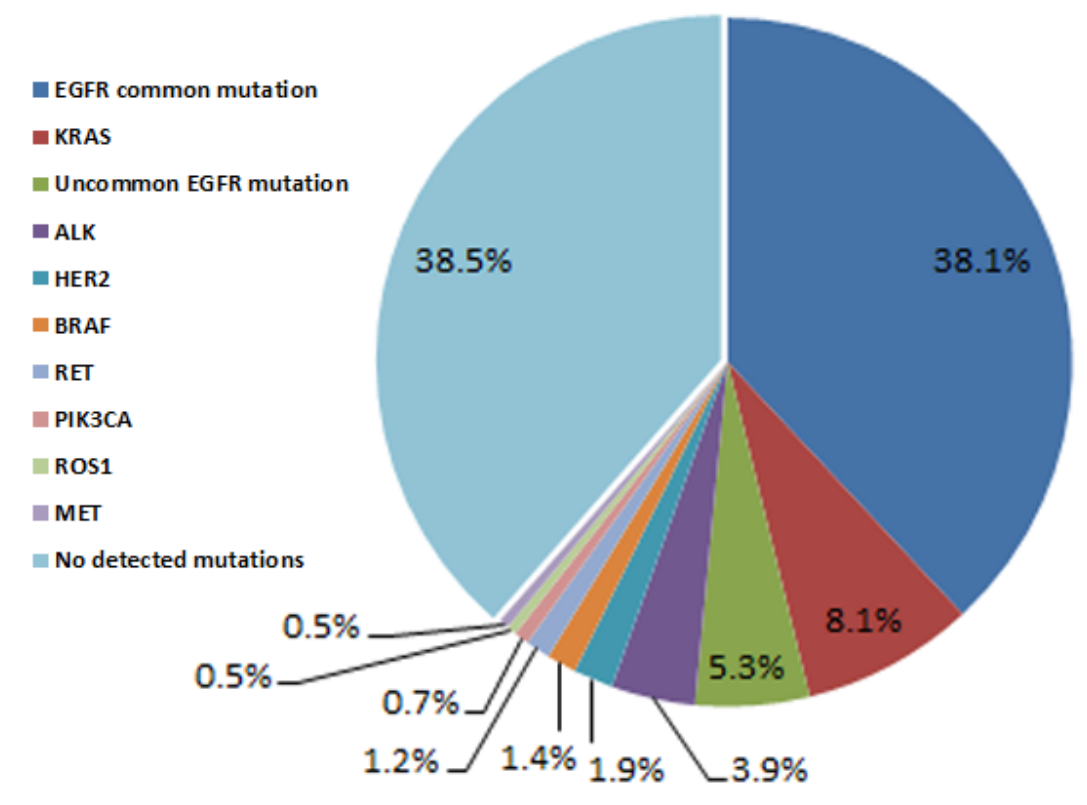

Adenocarcinoma or adenosquamous carcinoma

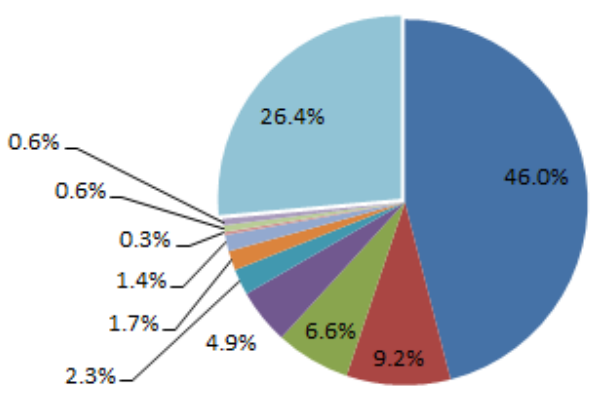

Squamous Carcinoma

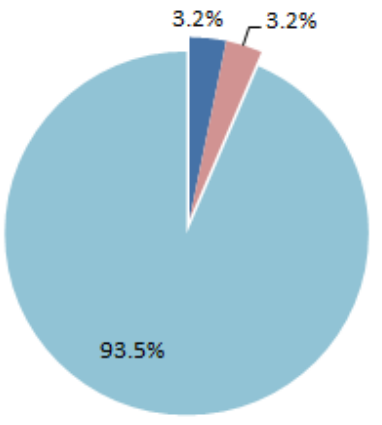

\section{Figure 1}

Profiling of oncogenic driver mutation in NSCLC patients. EGFR common mutation or rare mutations spectra were analyzed in all the enrolled patients, or in patients diagnosed as adenocarcinoma or adenosquamous carcinoma, and squamous carcinoma. 


\section{Survival of PFS1}

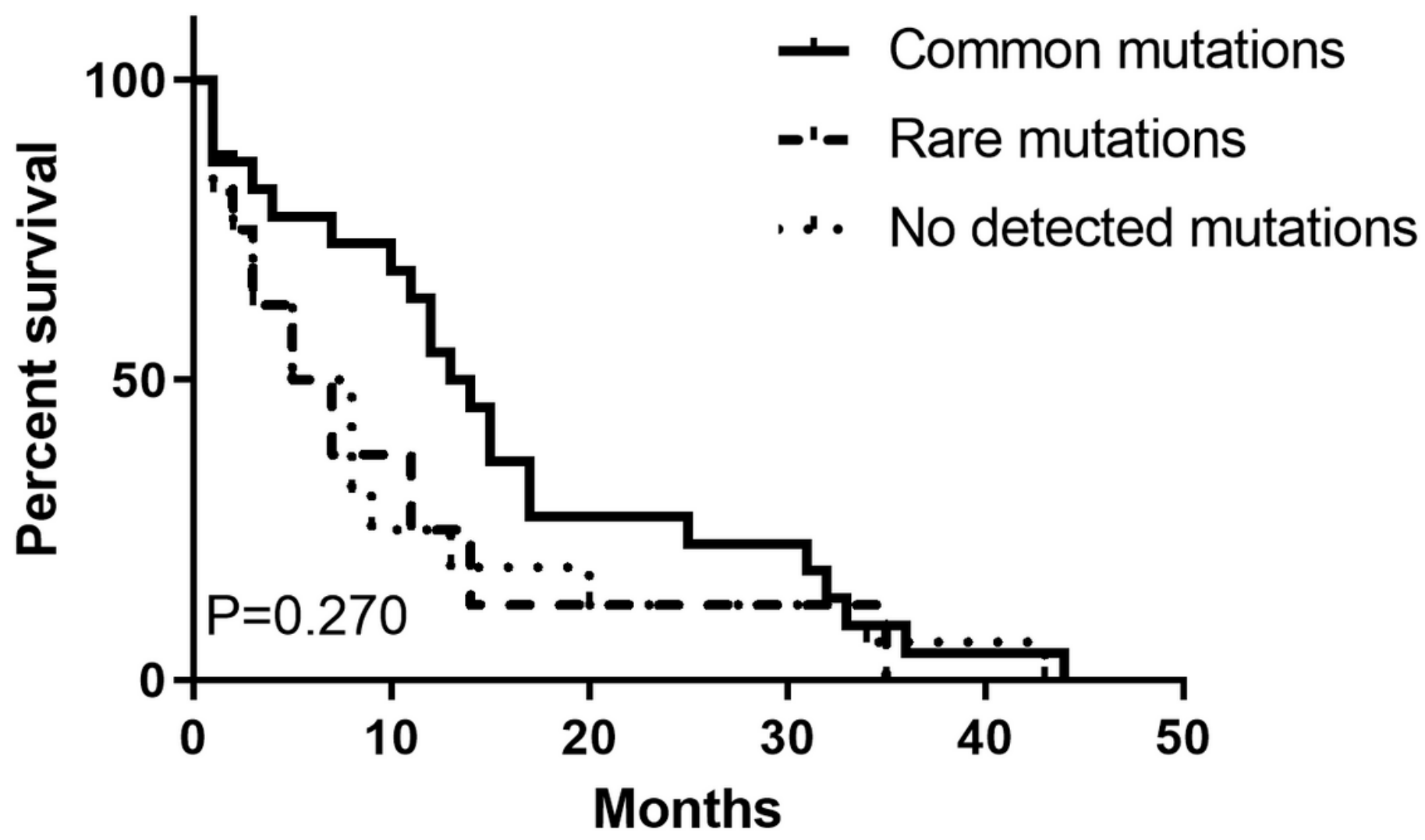

Figure 2

The PFS1 in the 46 patients with different mutation status. PFS1, progression-free survival of these two groups of patients receiving the first-line treatment 